\title{
Testing for the location of the Alamo Acequia (41BX8) at Hemisfair Plaza, San Antonio, Texas
}

Anne A. Fox

Follow this and additional works at: https://scholarworks.sfasu.edu/ita

Part of the American Material Culture Commons, Archaeological Anthropology Commons, Environmental Studies Commons, Other American Studies Commons, Other Arts and Humanities Commons, Other History of Art, Architecture, and Archaeology Commons, and the United States History Commons

Tell us how this article helped you.

This Article is brought to you for free and open access by the Center for Regional Heritage Research at SFA ScholarWorks. It has been accepted for inclusion in Index of Texas Archaeology: Open Access Gray Literature from the Lone Star State by an authorized editor of SFA ScholarWorks. For more information, please contact cdsscholarworks@sfasu.edu. 


\section{Testing for the location of the Alamo Acequia (41BX8) at Hemisfair Plaza, San}

Antonio, Texas

\section{Creative Commons License}

\section{(c) (1) (8)}

This work is licensed under a Creative Commons Attribution-NonCommercial 4.0 International License 


\section{TESTING FOR THE LOCATION OF \\ THE ALAMO ACEQUIA (4IBX 8) \\ AT HEMISFAIR PLAZA, SAN ANTONIO, TEXAS}

Anne A. Fox

Center for Archaeological Research

The University of Texas at San Antonio

Archaeological Survey Report, No. 142

1985 

TESTING FOR THE LOCATION OF

THE ALAMO ACEQUIA (4I BX 8)

AT HEMISFAIR PLAZA,

SAN ANTONIO, TEXAS

Anne A. Fox

Texas Antiquities Committee Permit No. 396

Thomas R. Hester, Principal Investigator

Center for Archaeological Research The University of Texas at San Antonioc Archaeological Survey Report, No. 142 
The following information is provided in accordance with General Rules of Practice and Procedure Chapter 41.11 (Investigation Reports), Texas Antiquities Committee:

1. Type of investigation: archaeological testing;

2. Project name: Alamo Acequia (41 BX 8) at HemisFair Plaza;

3. County: Bexar County, Texas;

4. Principal Investigators: Thomas R. Hester, Principal Investigator; Jack D. Eaton and Anne A. Fox, Co-Principal Investigators;

5. Name and location of sponsoring agency: City of San Antonio;

6. Texas Antiquities Committee Permit No. 396;

7. Published by the Center for Archaeological Research, The University of Texas at San Antonio, San Antonio, Texas 78285, 1985.

A 1 ist of publications offered by the Center for Archaeological Research can be obtained by sending $\$ 1.00$ to the Center for Archaeological Research, The University of Texas at San Antonio, San Antonio, Texas 78285. 


\begin{abstract}
In December 1983 the Center for Archaeological Research conducted test excavations at HemisFair Plaza in downtown San Antonic. The purpose of the work was to locate and document the condition of the Alamo Acequia (41 BX 8), which was known to be in the area. Backhoe and hand excavations revealed that the acequia deviated as much as 20 feet from the supposed route and that the original property 7 ines through the area could not be depended upon to locate the precise route of the ditch. The section of the acequia that was examined proved to be on $7 y$ partially preserved, apparently having been robbed of stone either in the early 20 th century or during Hemisfair construction.
\end{abstract}


TABLE OF CONTENTS

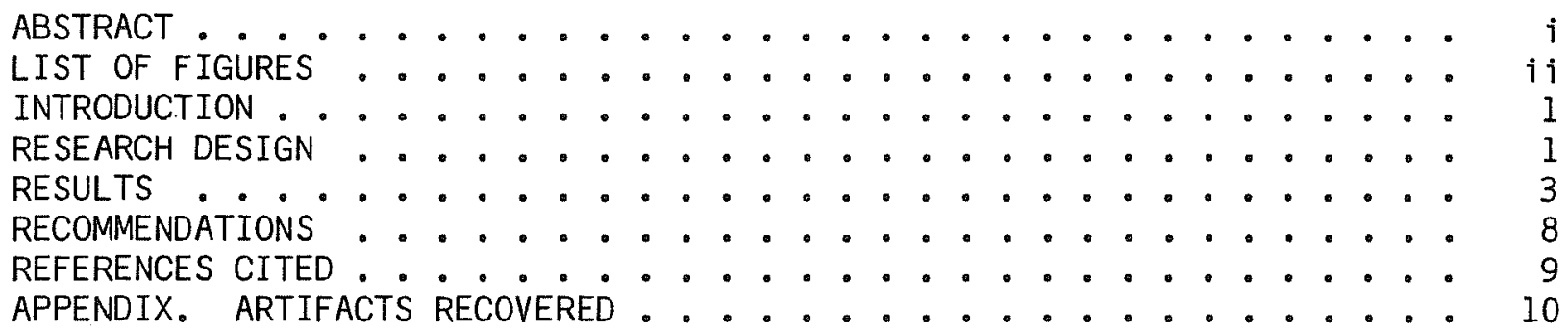

\section{LIST OF FIGURES}

1. Map of Hemisfair Plaza Showing Proposed Development Area . . . . 2

2. Map of Southwest Corner of HemisFair Plaza, Showing Location of Trenches 1 and 2 .............. 4

3. Map Showing Location of Trench 3 . . . . . . . . . . . 6

4. Profiles of Trenches 1, 2, and 3.............. 7

5. Sample of Artifacts Recovered ............... 11 


\section{INTRODUCTION}

In December 1983, the firm of Ford Powe 11 and Carson, Inc., requested the Center for Archaeological Research, The University of Texas at San Antonio, to do 1 imited archaeological testing at Hemisfair Plaza, located three blocks south of Alamo Plaza in downtown San Antonio. The Center then entered into a contract with the City of San Antonio to do the work. This was the second phase of what will be a multiphased investigation of the Hemisfair site in advance of extensive development work planned by the City in this area (see Fig. 1). Phase I was a 1 iterature and archival study (Cox and Fox 1983). The purpose of the second phase of work was to 1 ocate the exact route and assess the present condition of the Al amo Acequia (4I BX 8), or irrigation ditch, which is buried beneath the HemisFair site (Fig. 1). This work was done under Texas Antiquities Committee Permit No. 396 in accordance with Section 106 of the National Historic Preservation Act of 1966, as amended and the Council of Texas Archeologists" "Guidelines for Cultural Resource Management Reports."

The project was conducted under the general supervision of Dr. Thomas R. Hester, principal investigator and Jack D. Eaton, co-principal investigator. Anne A. Fox served as co-principal investigator and field director. The field work of locating and recording the acequia was done by Technical Staff Assistants Ralph Snavely and David Hafernik, under the supervision of the author. Three days were required to complete the work, which was done in two stages, on December 14 and 15, 1983, and February 15, 1984. The work in February was done with the aid of a backhoe. A1 1 notes, photographs, and artifacts are stored at the 1 aboratory of the Center for Archaeological Research.

\section{RESEARCH DESIGN}

The history of the construction and use of the Alamo Acequia Madre, or main ditch, has been summarized by Schuetz (1970:1-2) and Cox and Fox (1983:1415). The acequia was constructed between 1720 and 1724 as an open, un 1 ined ditch to irrigate the fields of Mission San Antonio de Valero ( 1 ater to be called the Alamo). Leaving the San Antonio River in what is now Brackenridge Park, the acequia ran east of the mission, where a branch provided water to the mission compound, then rejoined the main ditch just north of Goliad Street in HemisFair Plaza (Fig. 1) and returned to the river south of the King William area. The portion of the ditch that ran through the developed section of town was 1 ined with cut stone in the early 19 th century. The acequia was finally abandoned and filled between 1896 and 1904 (Cox and Fox 1983:16). A section of the acequia was excavated in 1966 (Schuetz 1970:1-13) and was filled with water as a feature in the patio of the Spanish Pavilion during Hemisfair. When the fair was under construction, the route of the acequia could readily be traced by observing the stone walls which 1 ine the ditch, about 50 feet of which were visible at the surface of the ground within the triangle formed at that time by South Alamo, Goliad, and Water Streets (Schuetz 1970:3; Fig. 1). The southern part of the Spanish Pavilion and other structures were then built over the acequia, effectively hiding its location. 


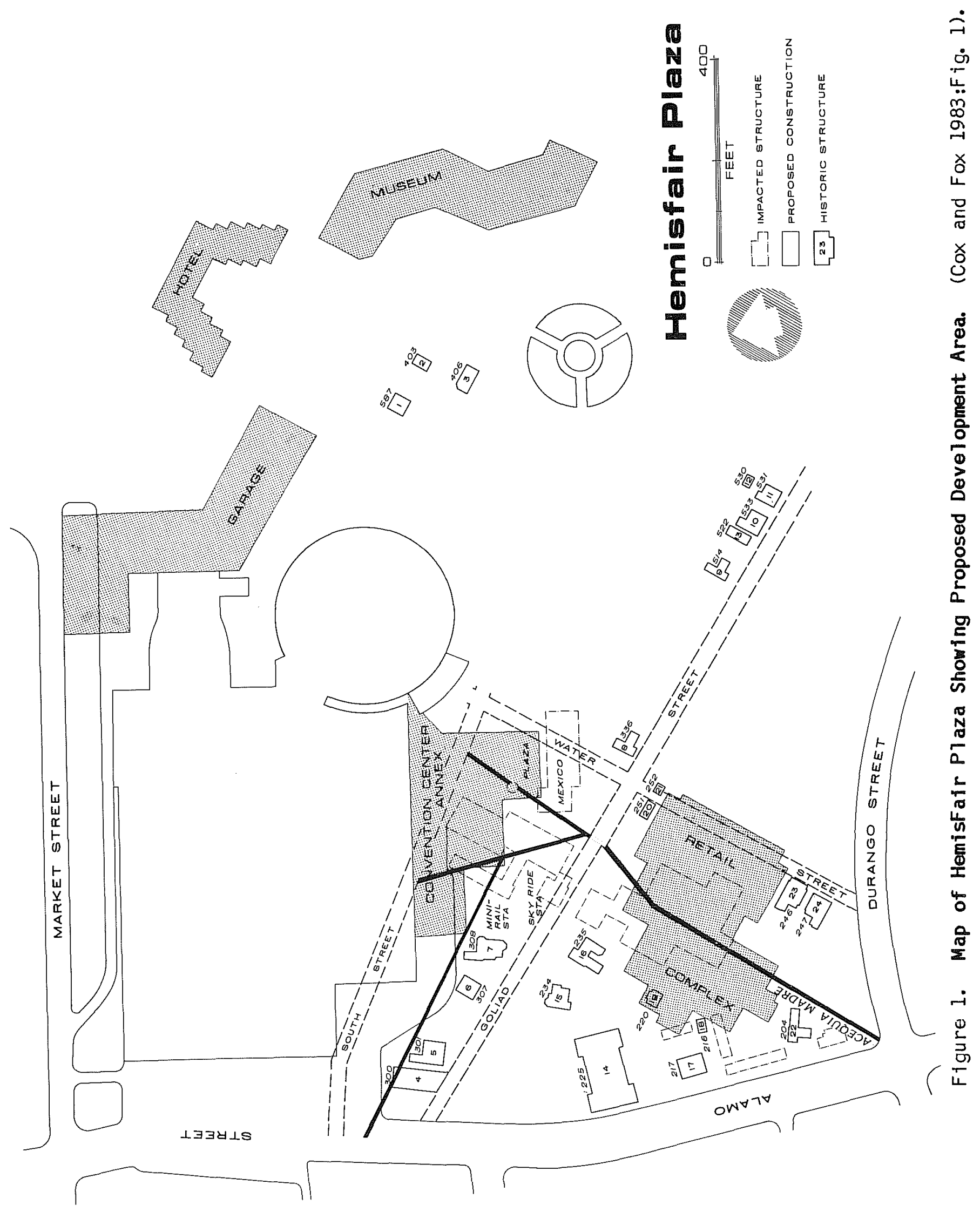


Unfortunately, the location of the acequia had not been accurately mapped while it was still visible. There are numerous early maps of San Antonio which show its approximate location, however. Two Sanborn insurance maps (Samborn Map and Publishing Company, Ltd. 1896 and 1904) appeared to be quite accurate in this regard, leading us to bel jeve that it would be fairly simple to find the stone-lined acequia by plotting its location on the ground and trenching across it. An accurate map of the HemisFair grounds was obtained, and the route of the ditch was transferred onto this map from the insurance maps. Armed with this composite map. Schuetz's recorded observations of the appearance and contents of the acequia, and the author's observations as a participant in the 1966 excavations, the crew felt we 11 prepared to begin the field work, which was planned to consist of hand excavation of trenches perpendicular to the acequia route.

\section{RESULTS}

On December 14, 1983, the archaeological crew laid out a three-foot-wide trench across an open, grassy area 35 feet southwest of the south wall of the old Spanish Pavilion, which today houses the Transportation Museum (Fig. 2, Trench 2). A 1 ine estimated to be about the centerline of the acequia was established perpendicular to the south wall of the Transportation Museum. The trench was located so as to cross the projected acequia route. A 10-foot section at the west end of this trench was excavated by hand, using picks and shovels, to a depth of ca. 20 inches. The soils consisted of six inches of sand, below which was a thin 1 ayer of dark brown clay over an eight-inch 1 ayer of pea gravel in a dark brown soil matrix. Beneath this was a layer of river cobbles which sat on a sheet of disintegrating polyethylene. Below the plastic was what appeared to be the original ground surface, a hard, dark gray to black clayey soil into which were pressed fragments of aqua bottle glass and animal bone. Cleaning off an inch of this soil, we found that the deposit was sterile, and that there had been no disturbance into this sterile soil along the entire length of this 10-foot section.

We then moved 6.5 feet east of the first section along the 1 ine of the trench and excavated another test unit ca. six feet long. The same sequence of sand, gravel, and dark brown soil with cobbles and plastic was found in this section of the trench. Beneath the plastic, however, at 19 inches there was a deposit of building rubble consisting of glazed ceramic tiles, mortar, and thick, unglazed tiles in a tan, calichelike deposit. There were also a few 1 ate 19th-century household items such as a lavender glass mug handle, a white glass canning jar 1id, a white glass button, and a fragment of a clear glass bottle. These objects resembled the sorts of materials found in the section of the acequia excavated in 1966 (Schuetz 1970:7-13).

Returning the next day, we began to excavate what we bel ieved to be the acequia, only to find that the deposit was only a few inches thick and bottomed out on the same dark brown sterile clay running undisturbed the length of the trench. At this point we had moved some 50 cubic feet of soil and still had not found the acequia. We adjourned to the 1 aboratory to restudy the problem. 
This page has been

redacted because it

contains restricted

information. 
On February 15, 1984, the crew returned to the Hemisfair site, this time with a backhoe. Three trenches were dug, two across the general route of the acequia (Fig. 2) and one across the route of a lateral ditch (which was fed by the acequia) north of the Transportation Museum (Fig. 3).

Trench 1 was 1 aid out across the point where the maps showed the acequia should cross the intersection of South Al amo and Lavaca Streets (which became the general location of Durango Street when Hemisfair was built). Near the west end of the trench an anomaly was recorded which consisted of an irregular intrusion of dark clay into the fairly regular caliche bedrock formation (Figs. 2 and 4 ). The only artifacts observed in the entire length of the trench were a few fragments of bottle glass and window pane glass and a sherd of white-banded yellow ware (see Appendix). Time did not allow further searching for the acequia in this area.

Trench 2 was a reexcavation and extension of the test units excavated in December. Starting at the west end of the original trench, where the acequia was purported to be located, we deepened the trench by several feet and found, as we had first postulated, that the area was total 1 y undisturbed below the HemisFair construction 1eve1. Continuing the trench east beyond our second test unit, we began to find random cut 1 imestone blocks at ca. 20 inches below the surface, and a deposit of packed, sterile caliche. Taking over from the backhoe, the crew excavated the caliche deposit and found it to be a lens of fill over the top and into the channel of the acequia. The combined evidence of the remaining 1 imestone wall at the east end of the trench and the deposit of artifacts (see Appendix). to the west of this wall still appearing at five feet below the surface (Fig. 3 ), convinced us that we had finally found the Alamo Acequia. The west wall of the ditch appeared to be in bad condition, perhaps due to disturbance and/or stone robbing during Hemisfair construction. Schuetz (1970:5) remarked that the top course of stone was missing from the section excavated in 1966, and the east wall in that area had been removed down to the bottom two courses in one section. It may be that the damage in the area we were examining had a 150 been done previous to 1966. A11 of the intrusive fill above the original ground surface was apparently brought in either as part of the construction effort for the fair or in an attempt to fill in a low area in more recent times after some of the fair buildings had been dismantled.

Trench 3 was 1 ocated across the route of a 1 ateral ditch which once ran to the northwest off the main acequia, toward Alamo Street (Fig. I). This lateral was seen on early maps primarily as a peculiar angle in the boundary 1 ine between properties in this area. While examining the early documents in preparation for the Phase I history, Cox discovered a reference to the 1 ateral in an appraisal of the property of Jose de 1 a Baume in 1841 (A1 amo Abstract \& Title Guaranty Company 1926). The backhoe trench was planned to cross the 1 ateral and yet to be in an unpaved area so as to avoid trenching through pavement. The only such spot which was readily reached by the backhoe was a grassy area to the east of the Mayer Halff house and south of the Convention Center (Fig. 3). Examination of the walls of the trench revealed the location of the lateral ditch, toward the south end of the trench (Fig. 4). As had been expected, the ditch is not stone 1 ined but merely a rather shallow trench dug into the soil. Apparently the top section was truncated by grading for HemisFair, eliminating the usual mound of earth 


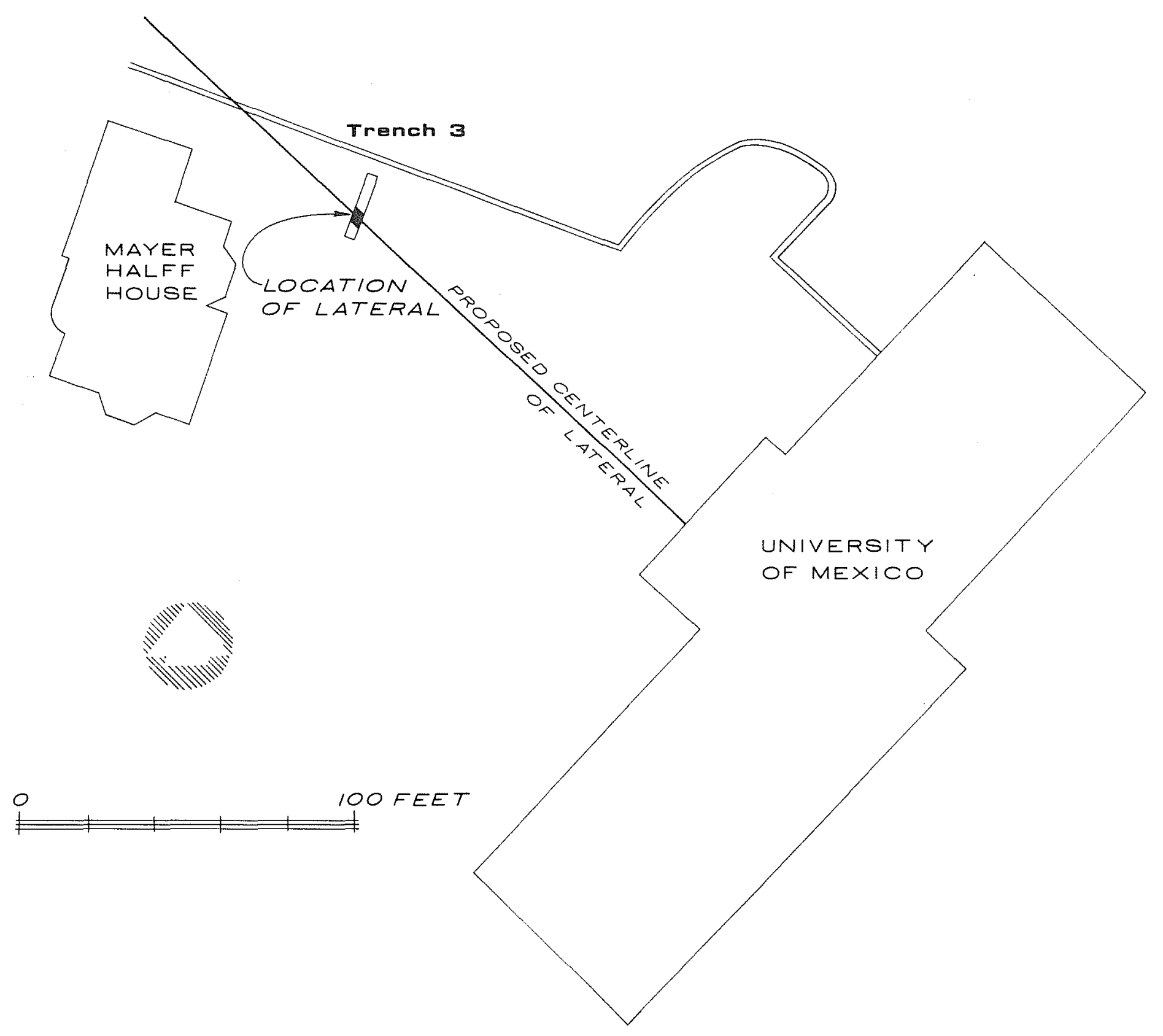

or

Figure 3. Map Showing Location of Trench 3. 


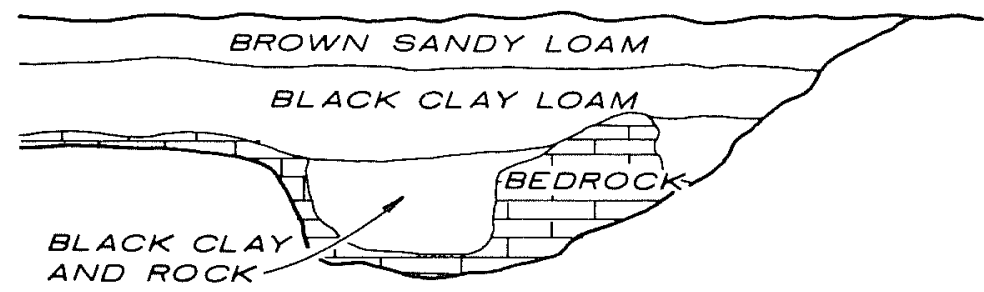

TRENCH 2

EABT END OF NORTH WALL

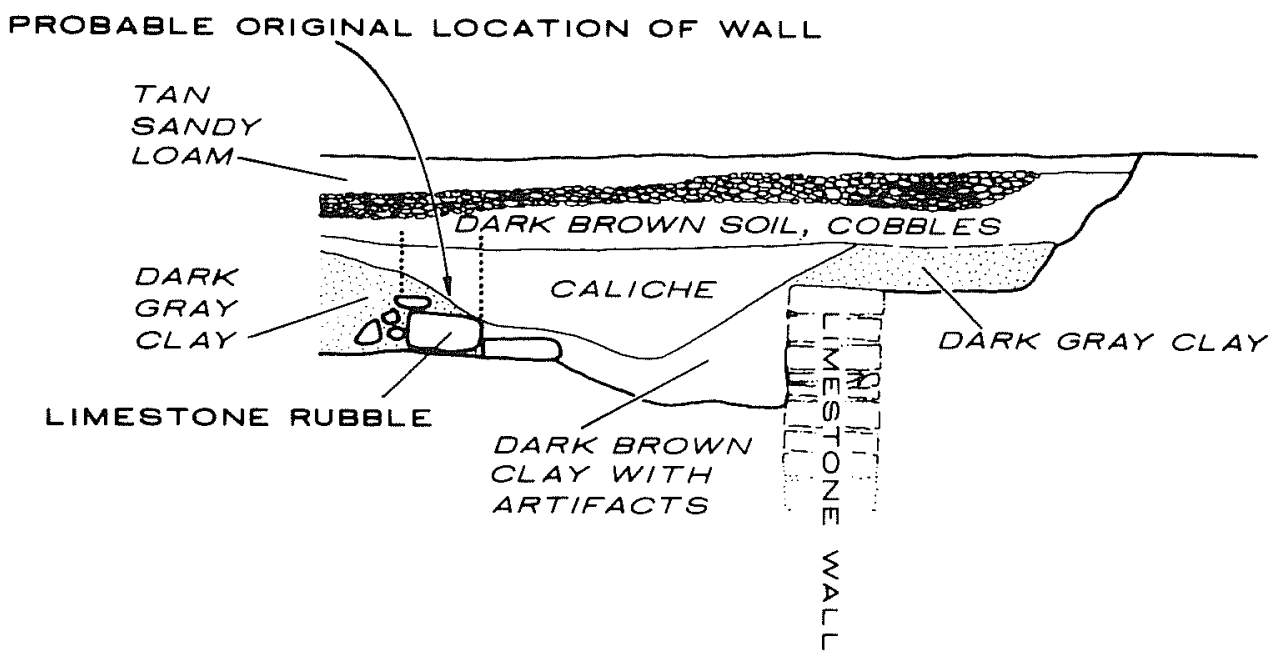

TRENCH 3 WEST WALL

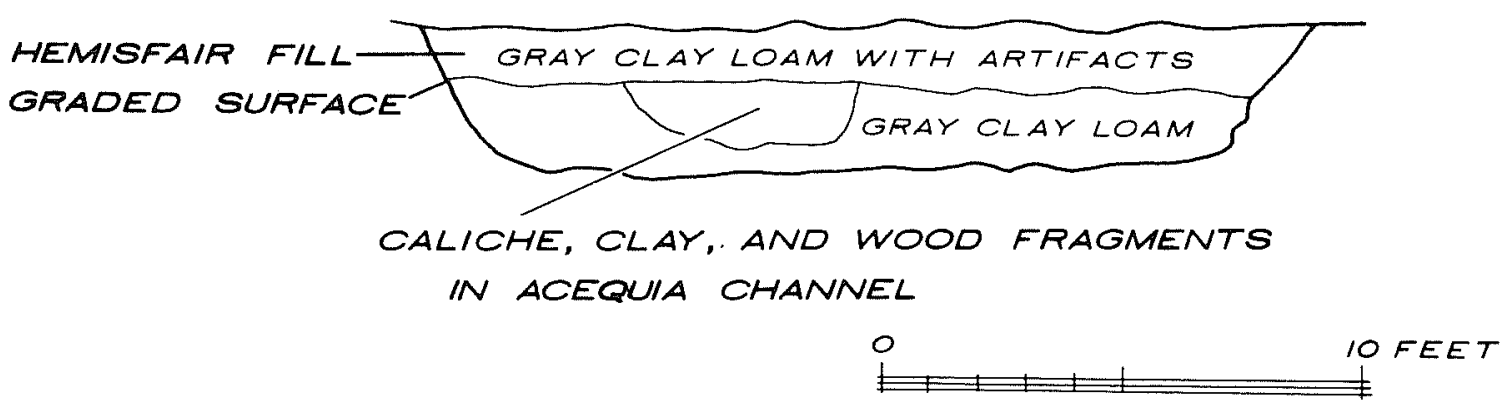

Figure 4. Profiles of Trenches 1, 2, and 3. 
on either side created by annual ditch cleaning. There is no way to be sure how much of the original ditch was also removed at the time of the grading, and therefore how deep it was original1y. Water for irrigation of the 1 ands to the west of the Alamo Acequia was allowed to flow into this ditch through a control gate for a certain number of hours each week on a regular schedule, depending upon the amount of 1 and to be irrigated (G T ick 1972:41-43). No artifacts were found in the ditch fill, which consisted of a loose accumulation of caliche, clay, and wood fragments, but numerous fragments of red and yellow brick and rusted metal and one sherd of white earthenware decorated with a contemporary transfer design (see Appendix) were found in the 1 ayer of soil above the graded surface level (Fig. 4).

\section{RECOMMENDATIONS}

From the results of our investigations, it appears that the $A 1$ amo Acequia (41 BX 8) is still in sufficiently good condition to be used as a basis for restoration of a 1 arger section of the channel, at least in the area directly south of the Transportation Museum. The fact that it does not run in a straight 1 ine from the section excavated in 1966 to the intersection of South A 1 amo and Durango Streets may create something of a challenge to the architects. It will probably be necessary to return to the area with a backhoe to determine what happens to the route of the acequia scuth of Trench 2, if the ditch is to be included in architectural plans. It is not possible at this time to determine what effect, if any, the construction of the Spanish Pavilion had on the acequia wall 15.

In the Phase I report (Cox and Fox 1983:17) we stated that the A7amo Acequia meets at least four important criteria for nomination to the National Register of Historic Places. Very briefly, these would include: (1) association with events that have made a significant contribution to the broad patterns of our history; (2) association with the 7 ives of persons significant in our past; (3) possesses distinctive characteristics of a type, period, or method of construction; and (4) have yielded, or may be likely to yield, information important in history. This investigation has served to reinforce our opinion, and we recommend that the City of San Antonio proceed with the nomination of the acequia. Using the same criteria, we also recommend that the acequia be made a State Archeological Landmark. We further recommend that monitoring of all construction which may impact the acequia is essential when the work begins on the HemisFair remodeling project. Particularly sensitive areas which should receive special care are the intersection of the two branches of the acequia, just north of Goliad Street and that of the 1 ateral with the west branch of the acequia to the northwest (Fig. 1). Control gates are 1 ikely to be still in place at these two locations, details of the construction of which would be of considerable historical interest. We would also urge the city at this time to consider the nomination of the other structures within the "Historic Triangle" on the Hemisfair Plaza to the National Register. 


\section{REFERENCES CITED}

Alamo Abstract \& Title Guaranty Company

1926 Abstract of Title No. 61123. Copy in the Daughters of the Republic of Texas Library. The Alamo, San Antonio.

Cox, I. W. and A. A. Fox

1983 Literature and Archival Study for the Development of HemisFair Plaza, San Antonio, Texas. Manuscript submitted to the City of San Antonio, April 1983, by the Center for Archaeological Research, The University of Texas at San Antonio.

Glick, T. F.

1972 The $01 d$ World Background of The Irrigation System of San Antonio, Texas. The University of Texas at E1 Paso, Southwestern Studies, Monograph 35.

Sanborn Map and Publishing Company, Ltd.

1896 Map of San Antonio, Texas. New York.

1904 Map of San Antonio, Texas. New York.

Schuetz, M. K.

1970 Excavation of a Section of the Acequia Madre in Bexar County, Texas, and Archeological Investigations at Mission San Josē in Apri1, 1968. Texas Historical Survey Committee, Archeological Report 19. 


\section{APPENDIX}

\section{ARTIFACTS RECOVERED}

The artifacts from the three trenches could be confidently dated to the late 19th century to the early 20 th century. Those from Trench 1, Level 1 of Trench 2, and Trench 3 were the type of artifacts generally found on the ground around late 19th-century houses and in dirt brought in to level yards for 1 andscaping. Those from Level 2 of Trench 2 consisted of household discards for the most part, such as broken dishes, utility wares used in the kitchen, flower pots such as would have been used in the house or yard, and the spring from a mattress or furniture cushion. Also present were a few wire nails, some clay tile, and fragments of window glass that may represent repairs to a building in the vicinity. The turn of the century date for this artifact collection confirms the 1896 to 1904 date for the abandonment and filling of the acequia in the HemisFair area.

Irench 1 (brown sandy loam, Fig. 4)

\section{Quantity Item}

$\begin{array}{ll}1 & \text { yel low ware } \\ 1 & \text { clear glass } \\ 1 & \text { flat glass }\end{array}$

\section{Description}

bow 1

cylindrical bottle window pane

Irench 2, Level 1 (dark brown soil with cobbles, Fig. 4)

$\begin{array}{cl}\text { Quantity } & \text { Item } \\ 1 & \text { undecorated porcelain } \\ 1 & \text { white glass } \\ 1 & \text { clear glass } \\ 1 & \text { lavender glass } \\ 1 & \text { flat glass } \\ 1 & \text { white glass button } \\ 2 & \text { clay tile, yellow tan }\end{array}$

\section{Description}

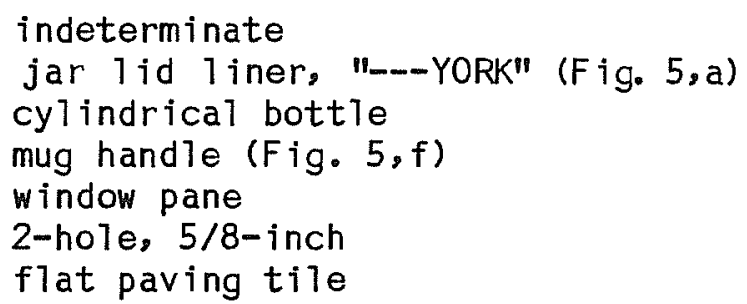

Irench 2. Level 2 (dark brown clay with artifacts, Fig. 4)

\begin{tabular}{|c|c|c|}
\hline Quantity & Item & Description \\
\hline 2 & undecorated white & \\
\hline 1 & $\begin{array}{l}\text { earthenware } \\
\text { gold-banded white }\end{array}$ & plates \\
\hline 6 & $\begin{array}{l}\text { earthenware } \\
\text { undecorated ironstone }\end{array}$ & $\begin{array}{l}\text { plate/saucer } \\
\text { plate, cup, pitcher } \\
\text { saucer }\end{array}$ \\
\hline $\begin{array}{l}1 \\
1\end{array}$ & $\begin{array}{l}\text { undecorated white porcelain } \\
\text { hand-painted porcelain }\end{array}$ & $\begin{array}{l}\text { saucer } \\
\text { cup/mug, aqua band, green and rose } \\
\text { (Fig. } 5, \text { b) }\end{array}$ \\
\hline 1 & yellow ware & mixing bow1 (Fig. $5, \mathrm{C}$ ) \\
\hline
\end{tabular}




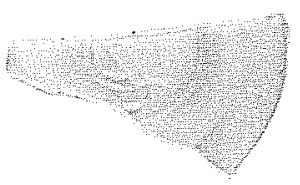

a

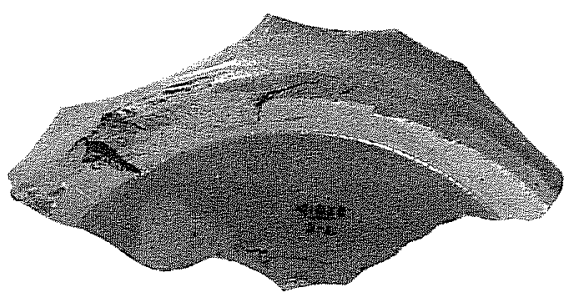

C

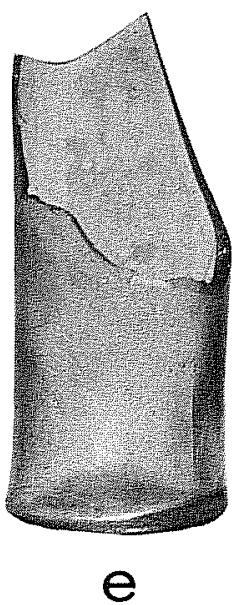

e

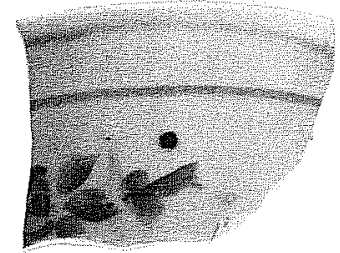

b

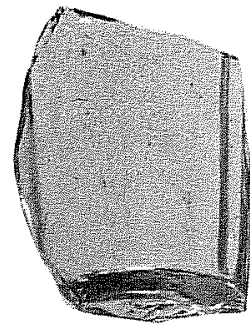

d

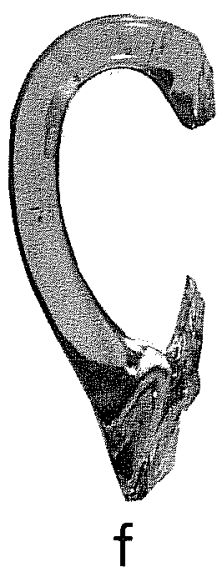

Figure 5. Sample of Artifacts Recovered. a, fragment of white glass jar 1 id 1 iner; b, hand-painted porcelain cup or mug sherd; $c$, yel low ware mixing bow 1 sherd; d, green, ribbed tumbler fragment; $e$, hand-blown aqua bottle fragment; $f$, lavender glass mug handle. 
Irench 2, Level 2 (continued)

\begin{tabular}{|c|c|c|}
\hline Quantity & Item & Description \\
\hline 2 & stoneware & $\begin{array}{l}\text { jug/crock, salt glaze and Albany } \\
\text { slip }\end{array}$ \\
\hline 2 & stoneware & jug. salt glaze and Albany slip \\
\hline 1 & unglazed earthenware & flowerpot \\
\hline 2 & unglazed earthenware & flowerpot saucer \\
\hline 2 & brown glass & cylindrical bottles \\
\hline 2 & brown glass & square bottle \\
\hline 1 & aqua glass & $\begin{array}{l}\text { cylindrical bottle, thin, hand } \\
\text { blown (Fig. } 5, e)\end{array}$ \\
\hline 1 & aqua glass & cylindrical bottle, soda \\
\hline 1 & blue green glass & coke bottle \\
\hline 1 & "black glass" & cylindrical bottle \\
\hline 1 & olive glass & wine bottle \\
\hline 1 & green-tinted glass & tumbler, ribbed (Fig. 5,d) \\
\hline 3 & clear glass & indeterminate \\
\hline 1 & clear glass & cylindrical bottle \\
\hline 1 & clear glass & cylindrical bottle, screw top \\
\hline 1 & clear glass & panel bottle, seam through lip \\
\hline 1 & aqua & $\begin{array}{l}\text { pane1 bottle, whole: DR.PIERCE'S } \\
\text { MEDICAL DISCOVERY, BUFFALO, N.Y. }\end{array}$ \\
\hline 1 & shell button & 2-hole, 1/2-inch \\
\hline 1 & flat glass & window pane \\
\hline 1 & stoneware & sewer tile \\
\hline 2 & unglazed ceramic & building tile \\
\hline 1 & wire spring & bed/couch \\
\hline 1 & wire & $3 / 16-$ inch \\
\hline 4 & wire nails & $2-1 / 2$ inch, 3 inch, and 4 inch \\
\hline 1 & heavy iron object & unidentified \\
\hline
\end{tabular}

Irench 3 (gray clay loam with artifacts, Fig. 4)

Quantity Item Description

1 white earthenware, blue transfer ware shallow bow 1 contemporary design 